\title{
The effect of carbon additives on crystal structure of coal tar pitch
}

\author{
(C) Anna N. Popova, ${ }^{+}$Galina P. Khohlova, Chingiz N. Barnakov, and Olga V. Grishaeva \\ Federal Research Center on Coal and Coal Chemistry. Siberian Branch, Russian Academy of Sciences. \\ Sovetsky Ave., 18. Kemerovo,650000.Russia.E-mail: h991@yandex.ru
}

\begin{abstract}
*Supervising author; ${ }^{+}$Corresponding author
Keywords: coal tar pitch, X-ray diffraction, X-ray structural analysis, crystal structure, carbon additives.
\end{abstract}

\begin{abstract}
The work is devoted to the study of changes in the basic structural characteristics of coal tar pitch during carbonization with various carbon additives that have different textural characteristics. An industrial medium-temperature coal tar pitch with a softening temperature of $87^{\circ} \mathrm{C}$ was taken as a starting material, nanosized carbon material "Kemerit", nanotubes, activated carbon, and thermally expanded graphite are considered as carbon additives. It was found in the work that the entire range of considered carbon additives significantly increases the yield of coke residue, while it was noted that a decrease in the amount of released volatile products during the destruction of pitch during its thermal transformation was observed, which is very important for carcinogenic compounds. Of the selected series of carbon additives, the maximum amount of solid residue is formed when nanostructured carbon additives (nanotubes and nanosized carbon material "Kemerit") are introduced into coal tar pitch. The structural characteristics of coal tar pitch before and after the carbonization process, as well as all carbon additives considered in the work, were investigated by the complex of X-ray diffraction methods (X-ray phase and X-ray structural methods of analysis). It was revealed that the formed carbon material, when nanotubes and Kemerite are added to coal tar pitch, is characterized by a more disordered structure when compared with the structure of individual coal tar pitch. The addition of thermally expanded graphite into coal tar pitch promotes the formation of graphite-like structures during pitch carbonization and reduces the amount of volatile carcinogenic compounds during thermal destruction to a greater extent when compared with amorphous carbon additives.
\end{abstract}

\section{References}

[1] V.K. Frizorger, V.V. Pingin, E.N. Marakushina, M.I. Krak, E.I. Andreikov, Yu.A. Dikovinkina. A method of obtaining a binder pitch with a reduced content of benzo [a] pyrene. Patent $R U 2671354 \mathrm{Cl}$. 2018. (russian)

[2] S.A. Sozinov, L.V. Sotnikova, A.N. Popova, and R.P. Kolmikov. Study of the film of $n$-hexane insoluble asphaltene produced from coal-tar pitch. Butlerov Communications. 2017. Vol.51. No.7. P.75-80. ROI: jbc-02/17-51-7-75

[3] Y. Cheng, Q. Zhang, Ch. Fang, Y. Ouyang, D. Liu. Co-Carbonization Behaviors of Petroleum Pitch. Waste SBS: Influence on Morphology and Structure of Resultant Cokes. J Anal Appl Pyrol. 2018. No.129. P.154-164.

[4] A.V. Nasibulin, A.V. Petrov, N.Yu. Beilina, G.S. Dogadin. Influence of the method of introducing a nanostructuring additive on the properties of coal tar pitch. Advances in chemistry and chemical technology. 2015. Vol.29. No.7(166). P.62-64. (russian)

[5] S.A. Sozinov, L.V. Sotnikova, Z.R. Ismagilov. Study of functional and group compositions of asphaltenes from coal-tar pitch. Chemistry for Sustainable Development. 2019. Vol.27. No.6. P.651-655. (russian)

[6] Ch.N. Barnakov, V.Yu. Malysheva, Z.R. Ismagilov. Evaluation of the relationship between the structure of graphite-like materials based on XRD data and the electrophysical properties of graphite materials anodes for LIB. Bulletin of the Kuzbass State Technical University. 2013. No.5. P.70-73. (russian)

[7] O.F. Sidorov. Carcinogenic activity of coal tar pitch depending on the technology of their production. Coke and chemistry. 2006. No.6. P.36-39. (russian)

[8] E.M. Malyutina, B.Sh. Dyskina, O.F. Korchazhkina. Method of obtaining pitch coke. Patent RU 2378320. 2010. No.1. (russian) 
[9] A.G. Anshits, V.A. Nizov, A.R. Suzdorf, V.I. Savinov. Method of obtaining anode mass. Patent RU 2088694. 1997. (russian)

[10] G.P. Khokhlova, A.N. Popova. Carbonization of coal pitch with graphite additives. Coke and Chemistry. 2016. Vol.59. No.1. P.27-34. (russian)

[11] Ch.N. Barnakov, V.Yu. Malysheva, Z.R. Ismagilov. X-ray diffraction analysis of the crystal structures of different graphites. Solid Fuel Chemistry. 2015. Vol.49. No.1. P.25-29. (russian)

[12] Ch.N. Barnakov, S.A. Sozinov, Z.R. Ismagilov. XRD characterization of the structure of graphites and carbon materials obtained by the low-temperature graphitization of coal tar pitch. Eurasian ChemicoTechnological Journal. 2015. Vol.17. No.2. P.87-93.

[13] G.P. Khokhlova, V.Yu. Malysheva. Influence of the nature and amount of the catalyst on the phase structure of the carbon material obtained by low-temperature catalytic graphitization of coal tar pitch. Bulletin of the Kuzbass State Technical University. 2013. No.5. P.21-24. (russian)

[14] G.P. Khokhlova, Ch.N. Barnakov, V.Yu. Malysheva. Effect of heat treatment conditions on the catalytic graphitization of coal-tar pitch. Solid Fuel Chemistry. 2015. Vol.49. No.2. P.66-72.

[15] Ch.N. Barnakov, G.P. Khohlova, A.I. Romanenko. Electrical conductivity of carbon materials based on coal-tar pitch with added graphite foam. Coke and Chemistry. 2018. Vol.61. No.5. P.179-183.

[16] G.P. Khokhlova, Ch.N. Barnakov. Influence of carbon additives on the thermal transformation of coal pitch. Coke and Chemistry. 2015. Vol.58. No.7. P.268-274.

[17] Ch. N. Barnakov, S.K. Seit-Ablaeva, A.P. Kozlov. Method of obtaining nanostructured carbon material. Patent RU 2206394. 2003. No.17. (russian)

[18] V.V. Avdeev, A.I. Finaenov, A.V. Yakovlev. Method of obtaining foam graphite and foam graphite obtained by this method. Patent $R U$ 2233794. 2004. No.22. (russian)

[19] ICDD, PDF-2 2011 (Database), edited by Dr. Surya Kalakkodu, International Centre for Diffraction Data, Newtown Square, PA, USA. 2011.

[20] A.N. Popova. The method of calculation of crystallographic characteristics of graphite. Butlerov Communications. 2017. Vol.51. No.7. P.86-90. DOI: 10.37952/ROI-jbc-01/17-51-7-86

[21] A.N. Popova. Crystallographic analysis of graphite by x-ray diffraction. Coke and Chemistry. 2017. Vol.60. No.9. P.361-365.

[22] Ch.N. Barnakov, G.P. Khohlova, A.I. Romanenko Structure and conductivity of carbon materials produced from coal pitch with carbon additives. Coke and chemistry. 2017. Vol.60. No.7. P.278-284. 